\title{
煙流動二層ゾーンモデルの流量仮定法による計算法 \\ CALCULATION METHOD OF TWO ZONES MODEL OF SMOKE MOVEMENT BY MEANS OF THE FLOW RATE ASSUMING METHOD
}

\author{
松下敬幸*, 寺井俊夫** \\ Takayuki MATSUSHITA and Toshio TERAI
}

\begin{abstract}
The basic equations of two zones model of smoke movement are derived by the basic theory of flow and these are expressed by the incidence matrix and the loop matrix of graph theory. If the air temperature is constant and $\mathrm{dP} / \mathrm{dt}=0$ in all rooms, then some different equations are derived by the combination of the basic equations. However when the approximation of $\left[T_{a}\right][I]\left\{w_{a}\right\} \approx[I]\left\{\bar{w} T_{a}\right\}$ is permitted, it is possible to ignore the differences.

The calculation methods by means of the Pressure Assuming Method and the Flow Rate Assuming Method are considered by the representation of the incidence matrix and the loop matrix in the condition of two zones smoke flow. When the net flows in all branches are used, it is able to adapt simply the calculation method of one zone perfect mixing model. It is not necessary to change the graph of the one zone model and it is efficient to adapt the calculation method by means of the Flow Rate Assuming Method for two zones model of smoke movement because of the preservation of the advantage of the reduced computing times.
\end{abstract}

Keywords: Smoke Movement, Flow Rate Assuming Method, Two Zones Model, Incidence Matrix, Loop Matrix 煙流動, 流量仮定法, 二層ソーンモデル, インシデンス行列, ループ行列

1.はじめに

火災初期や開口が大きい場合には、燃焼によって生じ た高温の煙と室内に流入してくる常温の空気とは二層を 形成する傾向を有する。このような場合には二層流とし ての取り扱いが可能となり、建物全体の煙伝播予測にお いても二層流に対応した計算を行なう必要がある。

火災時における二層を形成した室の開口よりの煙の流 れの取り扱いについては、各種方法がある。水理学にお ける堰の流れとの相似性に基づいた取り扱いをする方法 ${ }^{1)}$ や、二層流であっても同一水平面内での流れを適用する 方法 ${ }^{2,3)}$ などがある。堰との類似性を考虑した方法では、 開口での煙境界高さにより流量の極大值が存在するのに 対し、同一水平面内での流れの方法では境界面が床面に 来たときに流量が最大になる点で異なっている。ただし、 実用的には微小開口の流れを適用する方法が許容される1)。 従来の二層ゾーンの取り扱いにおいては流れは同一水 平面内で生じるとする場合が多いこと、完全混合の場合 の考え方 ${ }^{4)}$ がそのまま应張できることおよび火災初期を対
象とする場合には取り扱い方法の差が問題にならないこ とにより、三層流としての開口部での流れには同一水平 面内での流れの方法を採用して検討することにする。

同一水平面内での流れを適用した建物内での二層流と しての煙伝播に関する取り扱いについては、既に田中 ${ }^{3)}$ が 定式化しており、圧力仮定法に基づいた計算法を示して いる。しかし、完全混合の場合における流量仮定法によ

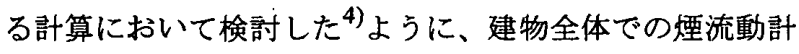
算において流量仮定法が有利になる場合が多くあるにも かかわらず、二層ゾーンモデルの流量仮定法による計算 法については従来検討されていない。完全混合の場合に ついてインシデンス行列及びループ行列5)を用いた表現8)

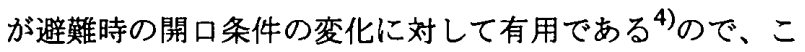
こでは煙流動二層ソーンモデルに対してインシテンス行 列及びループ行列を用いる方法を示した。さらに、変数 として開口部での煙流と空気流とを加え合わせた正味流 量を用いることにより計算が簡単になり、完全混合の場 合の手法をそのまま適用できることを示した。
* 神戸大学工学部建設学科 助手. 博士 (工学)
** 近畿大学工学部建築学科 教授.工博
Research Assoc., Dept. of Architecture and Civil Eng., Faculty of Eng., Kobe Univ., Dr. Eng.

Prof., Dept. of Architecture, Faculty of Eng., Kinki Univ., Dr. Eng. 


\section{2. 煙流彭計算における基磑式}

建筑火災時における建物内部での煙流動計算における 流れの場の決定に用いる基本式は、（1）理想気体の状態方 程式、(2) 犋量収支式、(3) 内部エネルギ収支式（熱収支 式）および(4) 運動エネルギ収支式、である。また、煙の 泿度の計算が必要な場合には、(5) 没度収支式、を追加す る必要があるが、煙泿度は流れに従属的に伝播され、流 れの場に影響しないと考えることができる。これらの式 は、それぞれ以下のように表わされる。

（1）状態方程式

建篡火災時における煙は空気と同等に取り扱うことが でき6)、完全ガスと考えてよい。従って、次の理想気体の 状態方程式を使用する。

$$
P=\rho R T
$$

(2) 翼量叹支

領域内部での連続の式は、

$$
\frac{\partial \rho}{\partial t}=-\nabla \cdot \rho \omega
$$

である7かから、これを領域全体について積分し、右辺第 1 項に発散定理（グリーンの公式）

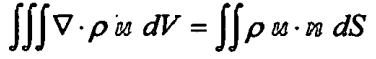

を用いることによって、次式が得られる。

$$
\iiint \frac{\partial \rho}{\partial t} d V+\iint \rho \infty \cdot p d S=0
$$

通常の輸送理論ではこの形で扱うことが普通であるが、 煙流動二層ソーンモデルの場合には煙層及び空気層体樌 の時間変化を考慮しなければならないため、(4)式の変形

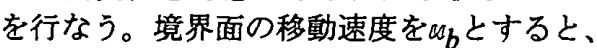

$$
\frac{d}{d t} \iiint \rho d V=\iiint \frac{\partial \rho}{\partial t} d V+\iint \rho{\varkappa_{b}}_{b} \cdot m d S
$$

の関係があるから、これを(4)式に代入することにより、 境界面の移動がある場合の式として次式を得る。

$$
\frac{d}{d t} \iiint \rho d V+\iint \rho\left(w-w_{b}\right) \cdot \mathbb{B} d S=0
$$

領域内を均一とすることができる場合には、 $\frac{d}{d t} \iiint \rho d V=\frac{d(\rho V)}{d t}$ が成立するから、次式を得る。

$$
\frac{d(\rho V)}{d t}+\iint \rho\left(u-w_{b}\right) \cdot x d S=0
$$

一層完全混合の場合のように境界面の移動がない場合

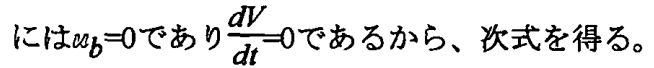

$$
V \frac{d \rho}{d t}+\iint \rho d s \cdot n d S=0
$$

(3) 内部エネルギ収支

領域内部での発生 $Q$ を考感するとき、輸送理論における 内部エネルギー式の通常の形は次式である7”。

$$
\frac{\partial \rho U}{\partial t}=-\nabla \cdot \rho U u-(\nabla \cdot Q)-P(\nabla \cdot u)-(\tau: \nabla u)+Q
$$

これを、領域全体について積分し、質量収支の場合と 同様に考えると、領域境界の移動を考虞した場合の関係 式として次式が得られる。 $\frac{d}{d t} \iiint \rho U d V+\iint \rho U\left(w-u_{b}\right) \cdot m d S$

$=-\iint q \cdot m d S+\iiint Q d V-\iiint P \nabla \cdot u s d V-\iiint \tau: \nabla u d V$

領域内部及びそれをとりまく環境の絶対圧力Pの時間変 化 $d P / d t$ は無視できないが、係数としての絶対圧力は変化 量がPの值そのものと比べて十分小さい場合には近似的に 一定と取り扱うことができる。この場合には、(9)式の右 辺第3項を変形して、次式を得る。

$$
\begin{aligned}
& \frac{d}{d t} \iiint \rho U d V+P \frac{d V}{d t}+\iint(\rho U+P)\left(u-u_{b}\right) \cdot \approx d S \\
& \quad=-\iint q \cdot n d S+\iiint Q d V-\iiint \tau: \nabla u d V
\end{aligned}
$$

領城内を均一とすることができる場合には次式を得る。 $\frac{d(\rho U V)}{d t}+P \frac{d V}{d t}+\iint(\rho U+P)\left(u-\omega_{b}\right) \cdot p d S$

$$
=-\iint q \cdot \infty \Omega d S+\iiint Q d V-\iiint \tau: \nabla u d V
$$

さて、内部エネルギーUについては、ある基鹤状態から の差で考えればよい。ここで扱う気体はすべて理想気体 と考えることができるとき、比熱が温度に独立に一定と すると次の関係がある。

$$
U=C_{v} T, U+\frac{P}{\rho}=C_{p} T, R=C_{p}-C_{v}
$$

ただし、 $C_{p}$ は定圧比熱、 $C_{\boldsymbol{v}}$ は定積比熱、Rはガス定数で ある。これらの関係式を用いて整理すると次式を得る。

$$
\frac{d\left(\rho C_{\mathrm{v}} T V\right)}{d t}+P \frac{d V}{d t}+\iint \rho C_{\mathrm{p}} T\left(w-\mathbb{u}_{\mathrm{b}}\right) \cdot v d S
$$$$
=-\iint q \cdot v r d S+\iiint Q d V-\iiint \tau: \nabla \omega d V
$$

この関係式を、状態方程式を用いて变形して、次式のよ うに表わすこともできる。

$$
\begin{gathered}
\frac{C_{\mathrm{v}} V}{R} \frac{d P}{d t}+\frac{C_{p} P}{R} \frac{d V}{d t}+\iint \rho C_{p} T\left(u-\omega_{b}\right) \cdot m d S \\
\quad=-\iint q \cdot m d S+\iiint Q d V-\iiint \tau: \nabla u d V
\end{gathered}
$$

なお、完全混合の場合のように境界面の移動がない場 合の温度を用いた表現は、(13)式より次式となる。

$$
\begin{aligned}
& \frac{C_{v} V}{R} \frac{d P}{d t}+\iint \rho C_{p} T \omega \cdot m d S \\
& \quad=-\iint \mathscr{q} \cdot n d S+\iiint Q d V-\iiint \tau: \nabla \omega d V
\end{aligned}
$$

(4) 遙勁エネルギ収支

運動エネルギーの輸送方程式は、次式で与えられる7)。 $\frac{\partial}{\partial t}\left(\frac{\rho u^{2}}{2}\right)=-\nabla \cdot \frac{\rho u^{2}}{2} w-u \cdot \nabla p-\omega \cdot[\nabla \cdot \tau]+\rho w \cdot g$

これを、領域全体について䅡分し、前と同様にして領 域境界の移動を考虑した場合の関俰式として次式が得ら れる。

$$
\begin{aligned}
& \frac{d}{d t} \iiint \frac{\rho u^{2}}{2} d V+\iint \frac{\rho u^{2}}{2}\left(w-w_{b}\right) \cdot m d S \\
& \quad=\iiint \rho \omega \cdot g d V-\iiint \& \cdot \nabla P d V-\iiint w \cdot[\nabla \cdot \tau] d V
\end{aligned}
$$

領域境界の移動がなく、領域内を均一とすることがで きる場合には次式を得る。 


$$
\frac{d\left(\frac{\rho u^{2}}{2} V\right)}{d t}+\iint \frac{\rho u^{2}}{2} u \cdot n d S
$$

$=\iiint \rho \boldsymbol{u} \cdot \boldsymbol{g} d V-\iiint \boldsymbol{u} \cdot \nabla P d V-\iiint \boldsymbol{u} \cdot[\nabla \cdot \boldsymbol{\tau}] d V$

ところで、ある高さを基準とした高さ方向の座標をるで 表すとすると、

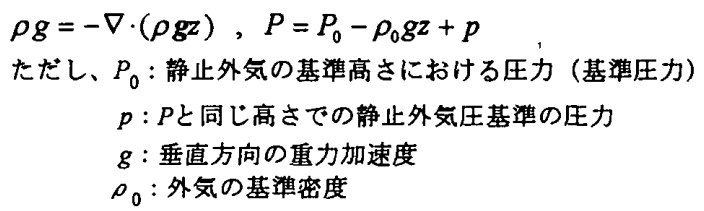

の関係がある。これらの関係を(17)式の右辺に用いて、次 式を得る。

$$
\begin{array}{r}
\frac{d\left(\frac{\rho u^{2}}{2} V\right)}{d t}+\iint \frac{\rho u^{2}}{2} u \cdot n d S=-\iint\left\{\left(\rho-\rho_{0}\right) g z+p\right\} u \cdot n d S \\
+\iiint\left\{\left(\rho-\rho_{0}\right) g z+p\right\} \nabla \cdot u d V-\iiint u \cdot[\nabla \cdot \tau] d V
\end{array}
$$

(5) 濃度収支

領域内部での発生を考慮した関係式は、次式となる。

$$
\iiint \frac{\partial \rho C}{\partial t} d V+\iint \rho C \boldsymbol{u} \cdot \boldsymbol{n} d S=\iiint W_{\mathrm{c}} d V
$$

（2）で行なったのと同様に考えると、領域境界面の 移動を考慮して、結局次式を得る。

$\frac{d}{d t}\left(\iiint \rho C d V\right)+\iint \rho C\left(\boldsymbol{u}-\boldsymbol{u}_{b}\right) \cdot \boldsymbol{n} d S=\iiint W_{c} d V$

領域内部が均一の場合には、次式を得る。

$$
\frac{d \rho C V}{d t}+\iint \rho C\left(\boldsymbol{u}-\boldsymbol{u}_{b}\right) \cdot \boldsymbol{n} d S=\iiint W_{c} d V
$$

境界の移動がない場合の関係式は次式となる。

$$
V \frac{d \rho C}{d t}+\iint \rho C u \cdot n d S=\iiint W_{c} d V
$$

\section{3. 二層ソーン煙流動計算に用いる基硔式}

通常の建築火災に上記の一般的な基礎式を適用する場 合、次のような仮定を行うことが許容される。

(a) 一区画または一室（以後『節点』という）内部での 空気または煙の層内は均質である。

(b) 各節点内部での流速は小さいとして無視し、節点 内部での運動エネルギは考えない。

(c) 節点内部の水平方向の圧力は等しく、瞬時に平衡す るものとする。

(d) 節点の内部エネルギ収支において、摩擦によるエ ネルギ消散は他の項と比べて小さいので無視する。

(e) 開口部（以後『枝』という）の体積は０とするが、 流れに対する抵抗は持つものとする。従って枝につ いては運動エネルギ収支のみを考える。

以上の仮定により、節点については(1),(6),(13),(21)式を、 また枝については(18)式のみを基礎式として用いることが できる。

ところで、(18)式の消散項（右辺第 3 項）は圧力損失の 形で表わされるとし、さらに枝の体積が０の仮定を導入 して右辺第 2 項を無視すると、ベルヌーイの式に圧力損

失項を加えた形になり、換気計算で用いられるような枝 の圧力差（隣り合う節点間の圧力差）と正味流量（枝の 規定された方向を正としたときの正負の流れの和）との 関係式に㷌せられる。二層流の場合でも、枝の正味質量 流量は、枝圧力差、煙層と空気層の温度および煙境界面 高さが与えられれば、解析的に計算できる。そのときの 一般的な表現は次のようになる。

$$
w=f(p, \rho, Y \text {,開口条件) }
$$

例えぱ、図-1のような場合、 $H_{1} \leqq h<Y_{i} 、 Y_{i} \leqq h<Y_{j}$ およ び $Y_{j} \leqq h \leqq H_{2}$ の 3 つの部分に分けてそれぞれの部分につ いて換気計算式を適用して枝の正味質量流量を求めるこ とができる。枝の向きを節点からj節点の方向とすると、 各部分の流れをまとめることにより、二層流の計算では 最大 4 種類の流れ（i節点からj節点に流出する煙流 $w_{s}^{+} 、 j$ 節点から $i$ 節点に流入する煙流 $w_{s}^{-} 、 i$ 節点から $j$ 節点に流出 する空気流 $w_{a}^{+} 、 j$ 節点から $i$ 節点に流入する空気流 $\left.w_{a}^{-}\right)$の 和として求められ、正味質量流量は次のように表現でき る。

$w=w_{s}^{+}-w_{s}^{-}+w_{a}^{+}-w_{a}^{-}$

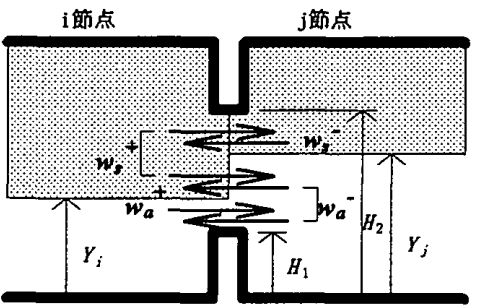

図-1 二層流の考え方

従って、煙流動計算における流れの場を決定するため に、節点に関しては(1),(6)および(13)式を、枝に関しては (23)式を基本式として用いればよい。また、濃度の計算に は、節点において(21)式を用いる。

二層流の場合にも室全体をひとつの節点と考えること ができるが、節点内部で煙と空気の二つの層があるので、 各層の体積が変化することを考慮することが必要となる。 一つの節点内の二つの層の境界面では $\boldsymbol{u}=\boldsymbol{u}_{b}$ である。

\section{(A) 節点での質量収支式}

煙層及び空気層の体積が時間的に変化することを考虑 する場合の、建物全体の節点および枝の接続関係を与え るインシデンス行列 $[I]$ を用いた表現を行なう。

(6)式より、煙層に対して次式を得る。

$$
\left\{\frac{d \rho_{s} V_{s}}{d t}\right\}+[I]\left\{w_{s}\right\}=\left\{W_{s}+\hat{w}\right\}
$$

ただし、Wsは火災時の分解生成物、燃焼生成物の煙層人

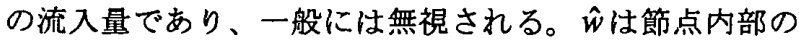
境界面を通して空気層から煙層に流入する質量流量であ り、ここでは火災プルームのみと考える。なお、同一節 点内での空気層から煙層に流入する火災プルームなどの 水平断面積は床面積に比べて無視できるものとする。 
空気層については、同様に次の関係式を得る。

$$
\left\{\frac{d \rho_{a} V_{a}}{d t}\right\}+[I]\left\{w_{a}\right\}=\{-\hat{w}\}
$$

(B) 節点での体積の関係

通常の建築火災においては、室の体積変化を考えるこ とはほとんどなく、煙層体皘 $V_{s}$ 、空気層体積 $V_{a}$ と室の全 体穞 $\mathrm{V}$ と間には次の関係が成立する。

$$
V_{s}+V_{a}=V=\text { const. }
$$

(C) 節点での熟収支式

節点における熱収支に関しても、(A)の質量収支と同様 に考える。(13)式より、粘性による発热項を無視して、次 式を得る。

$$
\left\{\frac{C_{\mathrm{v}} V_{s}}{R} \frac{d P}{d t}\right\}+\left\{\frac{C_{p} P}{R} \frac{d V_{s}}{d t}\right\}+C_{p}[I]\left\{\bar{w}_{s}\right\}=\left\{Q_{s}+\hat{Q}\right\}
$$

ただし、 $C_{p} \overline{w T}$ ，は煙層境界面を通しての正味の熟流出量 であり、枝の向きが節点からj節点の方向であるとき、 $i$ 節 点の煙温度を $T s_{i} 、 j$ 節点の温度を $T s_{j}$ とすると、 $\overline{w T}_{s}=w_{s}^{+} T_{s i}-w_{s}^{-} T_{s j}$ で定義される。 $Q$ 汹火災による発熱量 と境界面からの熱伝導による熱流入とを加えたものを意 味している。また $\hat{Q}$ 性同一節点内で空気層から煙層に流 入する火災発熱以外のエネルギー量であり、火災プルー 厶のみの場合には $C_{p} \hat{w} T_{a}$ で表される。

空気層についても同様に考え、次の関係式を得る。

$$
\left\{\frac{C_{v} V_{a}}{R} \frac{d P}{d t}\right\}+\left\{\frac{C_{p} P}{R} \frac{d V_{a}}{d t}\right\}+C_{p}[I]\left[\overline{w T} T_{a}\right\}=\left\{Q_{a}-\hat{Q}\right\}
$$

なお、煙首と空気層とを加え合わせて、(B)の条件（節 点の全体積が一定の関係）を用いると、節点全体の収支 式を得る。

$$
\left\{\frac{C_{v} V}{R} \frac{d P}{d t}\right\}+C_{p}[I]\left[\overline{w T}+\overline{w T}_{a}\right\}=\left\{Q_{a}+Q_{a}\right\}
$$

(D) 節点での煙没度収支

淈度収支に関しても同様に考えることができ、(21)式よ り、煙層に関して次の関係式を得る。

$$
\left\{\frac{d \rho_{s} C_{d} V_{s}}{d t}\right\}+[I]\left\{\overline{w C}_{s}\right\}=\left\{W_{c}\right\}
$$

(E) その他の関係

床面から天井までの高さを $H$ 、床面から煙層境界面まで の高さを $Y$ 、床面積を $A$ とすると、

$$
\begin{aligned}
& V_{s}=A(H-h) \\
& V_{a}=A Y
\end{aligned}
$$

である。

（F）一段の場合の構成式

\section{$(\mathrm{F}-1)$ 一般構成式の䛪尊}

一般の場合、未知数は $\rho_{s} 、 \rho_{a} 、 T_{s} 、 T_{a} 、 Y 、 P$ 6個で ある。従って、この場合の問題を解くには独立な関保式 を6個必要とする。なお、 $w_{s} 、 w_{a}$ も未知数であるが、温度、 圧力が与えられた場合には一意に決定し得る関数形が与 えられるために、ここでは従属的なものとし、独立変数 としては扱わない。また、通常の建築火災では $d P / d t=0$ と した取り扱いが許容されるので、この場合の潇成式につ
いても述べる。

ここでは、2 個の状態方程式の他に、(25)式、(26)式お よび(28),(29),(30)式の内から(28),(30)式の合計 6 つを独立 な式として選択する。なお、(29),(30)式の組合せでも、 (28),(30)式の組合せと同一の式を得ることが出来る。

基磁式誘道の流れを図一2に示す。

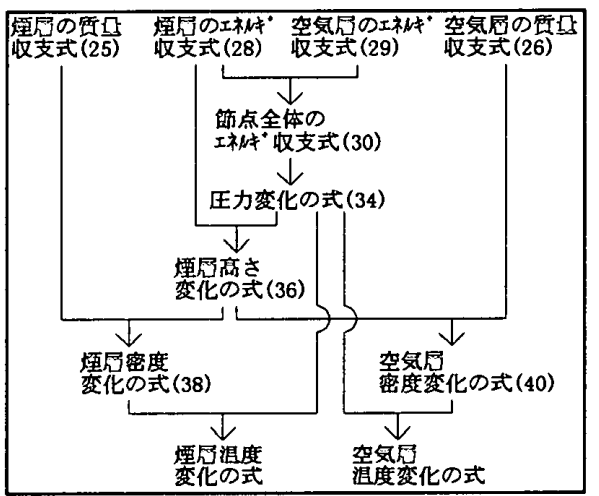

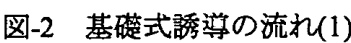

(30)式より、圧力変化の式を得る。

$$
\left\{\frac{C_{v} A H}{R} \frac{d P}{d t}\right\}+[I]\left\{C_{p}\left(\overline{w T}_{s}+\overline{w T}_{a}\right)\right\}=\left\{Q_{s}+Q_{a}\right\}
$$

圧力の時間変化項を無視できるとき、次式となる。

$$
[I]\left\{C_{p}\left(\overline{w T}+\overline{w T}_{a}\right)\right\}=\left\{Q_{s}+Q_{a}\right\}
$$

(28)式と(34)式より、高さ变化の式を得る。

$$
\begin{aligned}
& \left\{\frac{C_{p} A P}{R} \frac{d Y}{d t}\right\}-\left[\frac{Y}{H}\right][I]\left\{C_{p} \overline{w T},\right\}+\left[\frac{H-Y}{H}\right][I]\left\{C_{p} \overline{w T}_{a}\right\} \\
& =\left\{-\frac{Y}{H} Q_{s}+\frac{H-Y}{H} Q_{a}-\hat{Q}\right\}
\end{aligned}
$$

ただし、[Y/H]は対角要素が $Y / H$ の対角行列、[(H-Y)/H]は对 角要素が(H-Y)/Hの対角行列である。以下では、特別な注 意がない限りは、インシデンス行列[ []の前にかかる行列 は全て対角行列であるとする。なお、 $R / P=\rho_{s} T_{s}$ または $R / P=\rho_{a} T_{a}$ の関係を用いれぱ、R/Pを消去することができ る。压力の時間変化項を無視できる場合には、(35)式の関 係を用いて次式を得る。

$$
\left\{\frac{C_{p} A P}{R} \frac{d Y}{d t}\right\}-[I]\left\{C_{p} \overline{w T} s\right\}=-\left\{Q_{s}+\hat{Q}\right\}
$$

(25)式と(36)式より、煙層密度変化の式を得る。

$$
\begin{gathered}
\left\{C_{p} T_{s} A(H-Y) \frac{d \rho_{s}}{d t}\right\}-\left[\frac{Y}{H}\right][I]\left\{C_{p} \overline{w T} \bar{T}_{s}\right\}+\left[\frac{H-Y}{H}\right][I]\left\{C_{p} \overline{w T}_{a}\right\}_{(38)} \\
=\left\{-\frac{Y}{H} Q_{s}+\frac{H-Y}{H} Q_{a}-\hat{Q}\right\}-\left[C_{p} T_{s}\right][I]\left\{w_{s}\right\}+\left\{C_{p} T_{s} \hat{\omega}\right\}
\end{gathered}
$$

(38)式及び状態方程式より、煙層温度変化の式を得るこ とができる。圧力の時間変化項を無梘できる場合には、

(35)式の関係を用い、次の煙層の温度变化の式を得る。

$$
\begin{aligned}
& \left\{C_{p} A(H-Y) \rho_{s} \frac{d T_{s}}{d t}\right\}+[I]\left\{C_{p} \overline{w T}\right\} \\
& \quad=\left\{Q_{s}+\hat{Q}\right\}+\left[C_{p} T_{s}\right][I]\left\{w_{s}\right\}-\left\{C_{p} T_{s} \hat{w}\right\}
\end{aligned}
$$

(26)式と(36)式より、空気層密度变化の式を得る。 


$$
\begin{aligned}
& \left\{C_{p} T_{a} A Y \frac{d \rho_{a}}{d t}\right\}+\left[\frac{Y}{H}\right][I]\left\{C_{p} \overline{w T}\right\}-\left[\frac{H-Y}{H}\right][I]\left\{C_{p} \overline{w T}_{a}\right\} \\
& =\left\{\frac{Y}{H} Q_{s}-\frac{H-Y}{H} Q_{a}+\hat{Q}\right\}-\left[C_{p} T_{a}\right][I]\left\{w_{a}\right\}-\left\{C_{p} T_{a} \hat{w}\right\}
\end{aligned}
$$

煙首の場合と同様にして、圧力の時間変化項を無視で きる場合には、次の空気層の温度変化の式を得る。

$$
\begin{aligned}
& \left\{C_{p} A Y \rho_{a} \frac{d T_{a}}{d t}\right\}+[I]\left[C_{p} \overline{w T} T_{a}\right\} \\
& \quad=\left\{Q_{a}-\hat{Q}\right\}+\left[C_{p} T_{a}\right][I]\left\{w_{a}\right\}+\left\{C_{p} T_{a} \hat{w}\right\}
\end{aligned}
$$

\section{$(\mathrm{F}-2)$ 一般構成式の誘導 (別法)}

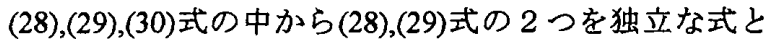
して選択することにより、図-3のような手順でも、上記の ものと同一の式を導くことが出来る。

インシデンス行列表現ではないが、この考え方に従っ て式を誘導したのが、田中が使用した式了)である。ただし、 田中の式は温度変化·圧力変化の関係式の誘導に、各成分 の物質収支を使用しているが、ここでは各成分について の扱いは行わず、全成分の質量収支としてまとめた。

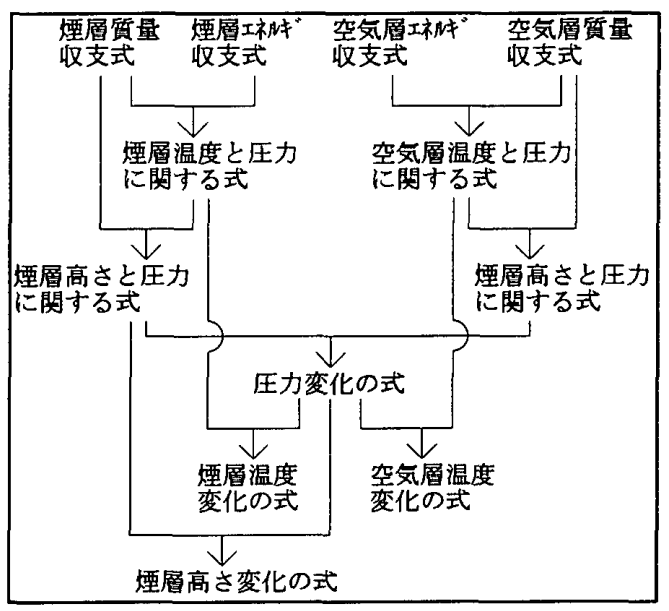

図-3 基礰式誘導の流れ(2)

\section{4. 空気層温度が一定、 $d P / d t=0$ の場合の構成式}

通常の建築火災の場合、絶対圧力の時間変化 $d P / d t$ を考 慮せず、圧力は瞬時に平衡するとし、その圧力場で発生 する微小な圧力差のみが流れの場に影響すると考えると いう近似が許されることが多い。また、煙層と空気層と の混合が小さく、空気層は放射に対して透明であるとし、 また空気層への熱伝達は小さいと仮定して空気首の温度 変化を無視してもよい場合が多い。

この場合、絶対圧力については一定とみなしたとして も、流れを引き起こす圧力差を考虑する必要があり、圧 力場を決定するための関係式が必要である。従って、压 力は未知数として残ることになる。

圧力が未知数として残るために、未知数は $\rho_{s} 、 T 、 Y$ 、 $P$ P 4 個であり、状態方程式 $\left(\rho_{s} T_{s}=\right.$ const. $)$ 以外に 3 個の 独立な関係式が必要である。従って、(25)式および (26),(28),(29),(30)式の内のどれか 2 個が必要である。
この場合、基䊙式としては、上記の組み合わせの仕方 により、多少の差異を生じた式を得ることになる。組み 合わせとしては、少なくとも煙層についての質量収支と エネルギ収支を使用することが条件であるので、(1) (25),(26),(30)式を用いる場合（節点内全体のエネルギー収 支を考慮する方法であり、Q ${ }_{a}$ の厳密な決定には(29)式を必 要とする) (2)(25),(26),(28)式を用いる場合（空気層の質量 収支を考慮し、空気層のエネルギ収支式を使用しない組 み合わせ）や(3)一般式において Ta=const.及び $d P / d t=0$ とお く場合（結果として、空気層の質量収支式を使用せず、 煙層と空気層のエネルギー収支を用いる組み合わせであ り、(25),(28),(29)式を使用する)、が考えられる。

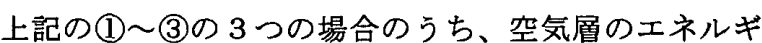
収支は暗黙の内に成立しているとする(2)が最も妥当であ ると考えられるが、以下で(1) (3)の差異について検討を 加える。

図-4のごとき煙層と空気層とが二層を形成した室を考え る。火災室でのみ空気層から煙層へのプルームが存在し、 また、隣室煙層から流入した煙は空気層には流入せず、 その逆に煙層への空気の流入もないとする。また、熱工 ネルギ収支式は節点での壁への熱伝達や燃焼による発熱 などの発熱項を含む。その表現法には精粗様々な取り扱 い方があるが、ここではその取り扱い方を論ずることが 目的ではなく、計算法を示すことが目的なので、完全混 合の場合と同様に発熱項は既知とした処理を行う。

\section{(A) 煙層高さの時間変化}

煙層高さの時間変化の式としては、(26),(28)または(29) 式のいずれかから得られる式を使用すればよい。方法(1) 及び(2)での(26)式を用いる場合、次式を得る。

$$
\left\{A \rho_{a} \frac{d Y}{d t}\right\}+[I]\left\{w_{a}\right\}=\{-\hat{w}\}
$$

あるいは、方法(2)及び(3)での煙層のエネルギ収支式(28) を用いる場合、次式を得る。

$$
\left\{A C_{p} \rho_{s} T_{s} \frac{d Y}{d t}\right\}=C_{p}[I]\{\overline{w T} s\}-\left\{Q_{s}\right\}-\left\{C_{p} \hat{w} T_{a}\right\}
$$

この式は(36)式に(35)式の関係を用いたものと同一である。

また、方法(3)では(29)式から得られる式を用いてもよい。

$$
\left\{A C_{p} \rho_{a} T_{a} \frac{d Y}{d t}\right\}+C_{p}[I]\left\{\overline{w T}_{a}\right\}=\left\{Q_{a}-C_{p} \hat{w} T_{a}\right\}
$$

(B) 煙層温度の時間変化

方法(2)及び(3)では、煙首の流量収支式(25)とエネルギ収
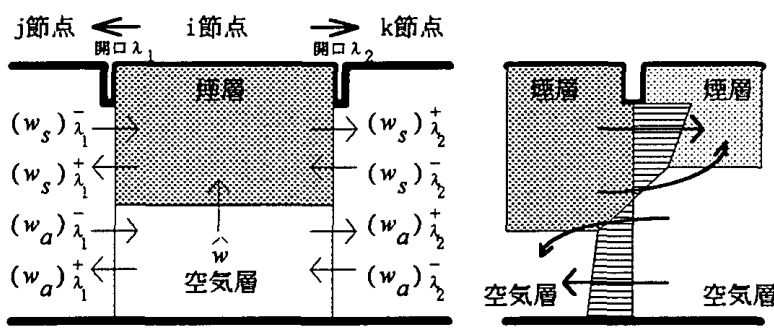

図-4 二層流の取り扱いの概略図 
支式(28)とから煙層温度の時間变化についての次式を得る。

$$
\begin{aligned}
\left\{A(H-Y) C_{p} \rho_{s} \frac{d T_{s}}{d t}\right\}= & C_{p}\left[T_{s}\right][I]\left\{w_{s}\right\}-C_{p}[I]\{\overline{w T} s\} \\
& +\left\{\hat{Q}_{s}\right\}+\left\{C_{p} \hat{w}\left(T_{a}-T_{s}\right)\right\}
\end{aligned}
$$

これは(39)式に(29)式の関係を用いたものと同一である。 方法(1)では、(25)式と(26)式とから、次式を得る。

$$
\begin{aligned}
\left\{C_{p} A(H-Y) \rho_{s} \frac{d T_{s}}{d t}\right\}= & -\left[C_{p} T_{s}\right][I]\left[w_{s}\right]-\left[C_{p} T_{a}\right][I]\left[w_{a}\right\} \\
& +\left\{C_{p}\left(T_{s}-T_{a}\right) \hat{w}\right\}
\end{aligned}
$$

(C) 節点全体での流量叹支

流れの圧力場を規定する関係式は、方法(1)及び(3)考 え方に従う場合、(30)式を使用する。

$$
\{0\}=-C_{p}[I][\overline{w T}\}+\left\{Q_{s}+Q_{a}\right\}
$$

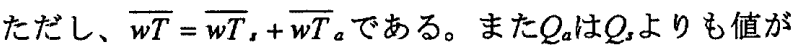
小さいとして、 $Q_{a}=0$ が近似的に成立すると考えてよい場 合が多い。なお、この式は(35)式と同一である。

この式は、節点に正味に流入するエネルギーと発熱量 は敛り合っていること、上下各首の境界移動による仕事 については節点全体については打ち消し合うことを意味 している。

方法(2)では、(42)式と(43)式から、次式を得る。

$\{0\}=-\left[C_{p} T_{a}\right][I]\left[w_{a}\right]-C_{p}[I][\overline{w T}]+,\left\{Q_{s}\right\}$

(D)枝圧力差的節点圧力 $P$ との関综

節点の圧力と開口での圧力差との関係は次式で与えら れる。

$$
\{\boldsymbol{p}\}+\left\{\boldsymbol{p}_{\sigma}\right\}=\left[I^{\prime}\right]\{P\}
$$

ただし、 $p_{\sigma}$ は風圧カやファンなどによる起圧力であり、

[I']仙[ ] 転置行列である。

(E)謤導方法の差異による粠成式の差異

誘導方法(1) (3)の 3 つの場合の槽成式の相違点は次の ようにまとめられる。

(2)と (3)とでは、煙層高さおよび煙層温度の变化の式は 同一であるが、压力場を決定するための節点全体の収支 式において差異が発生する。また、(1)と(3)とでは、圧力 場を決定するための節点全体の収支式は同一であるが、 煙層高さおよび煙層温度の変化の式に差異がある。なお、 次の近似が成立する場合には、(1) (3)忙同一となる。

$$
\left[T_{a}\right][I]\left\{w_{a}\right\} \approx[I]\left\{\overline{w T}_{a}\right\}
$$

空気首温度が一定かつ $d P / d t=0$ を仮定する場合の煙流動 計算では、空気層に関してはこの近似は成立すると考え られるので、(1) (3)の組み合わせのどれを用いてもよい。

\section{5. 圧力仮定法による計算法}

ここでは空気層温度が一定かつ $d P / d t=0$ 場合について、 インシデンス行列を用いた圧力仮定法による非定常二層 流煙流動計算の計算の流れを示す。

圧力仮定法により計算を行なうとき、床面圧力の仮定 值がもたらす節点での流量収支の誤差の補正を行なうた
めの関係式を必要とする。ここでは、床面圧力の仮定值 の補正にはNewton法による方法を用いるものとする。た だし、節点内全体における流量収支式としては、非定常 完全混合の場合と同様に、(47)式を用いるものとする。こ のとき、節点でのエネルギー流量収支誤差 $\{\Delta Q\}$ と節点の 床面圧力の誤差 $\{\Delta P\}$ との間には、次の関倸が成立する。 (Appendix(1)参照)

$$
\{\Delta P\}=\left([I]\left[\frac{\partial \overline{w T}}{\partial p}\right]\left[I^{\prime}\right]\right)^{-1}\{\Delta Q\}
$$

ただし、 $\left[\frac{\partial \overline{w T}}{\partial p}\right]$ は対角行列であり、対角要素は次の值で 定義される。

$$
\begin{aligned}
\frac{\partial \overline{w T}}{\partial p} & =\frac{\partial \overline{w T}_{s}}{\partial p}+\frac{\partial \overline{w T}_{a}}{\partial p} \\
& =\left(\frac{\partial w_{s}^{+}}{\partial p} T_{m}-\frac{\partial w_{s}^{-}}{\partial p} T_{v}\right)+\left(\frac{\partial w_{a}^{+}}{\partial p} T_{a t}-\frac{\partial w_{a}^{-}}{\partial p} T_{a}\right)
\end{aligned}
$$

節点全体での流量収支式(47)式が許容範囲内で満足され ない場合には(51)式より $\triangle P$ を求め、 $\{P-c \cdot \Delta P\}$ により、 節点の床面圧力の補正を行なう。ただし、cは補正保数で あり、通常0.6程度の値を使用する。

圧力仮定法による計算の流れを図-5に示す。インシデン ス行列の作成は前述の完全混合の場合と全く同様に作成 し、初期条件の与え方は完全混合の場合と全く同様でよ い。境界面高さ、節点温度の時間的な変化を求めるため に例えば(42),(45)式を使用する。

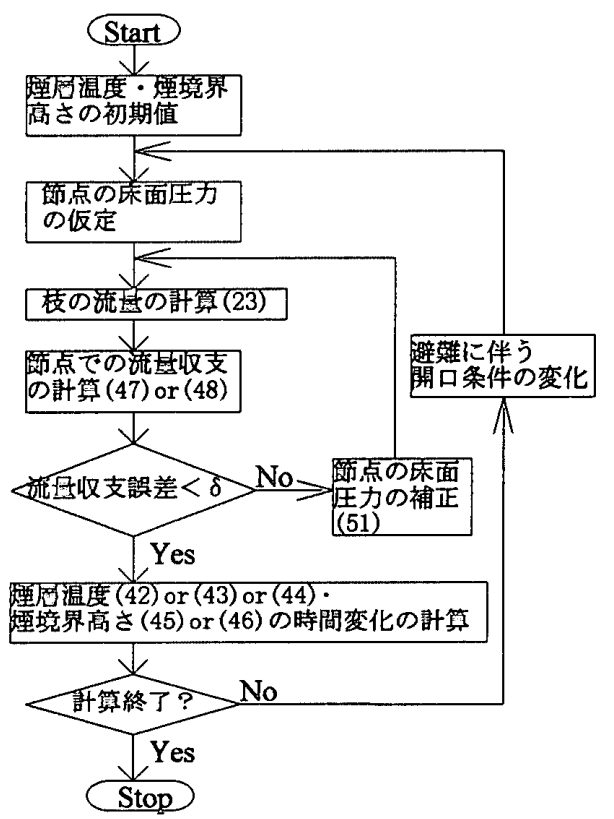

図-5＼cjkstart圧力仮定法による非定常二層流計算の流れ

\section{6. 流量仮定法による計算法}

従来の二層流の煙流動計算法は、前節のインシデンス 行列を用いた計算手順に従わないまでも、全てが「圧力 仮定法」を用いていた ${ }^{3,8)}$ 。これまで、二層流の計算に 「流量仮定法」を適用したものはなく、定式化もなされ 


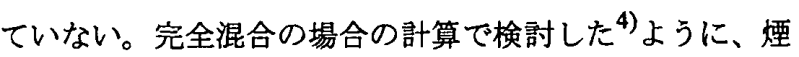
流動計算に㧍いては解くべき連立方程式の元数が計算時 間への影響の点で支配的である。圧力仮定法での連立方 程式の元数は(節点数-1)であり、流量仮定法での元数は(枝 数-節点数+1)である。高屏建築物における堅穴での煙流動 を正確に取り扱うために㹂穴を分割する場合などでは、 流量仮定法の方が連立方程式の元数が小さくなることが 多いために、流量仮定法が有力かつ有利な計算法となる。

§5の圧力仮定法による定式化で示したように、二層流 の場合であっても、基本的な考え方は完全混合の場合と 全く同様であり、各時間における温度の条件のもとで、 流れの場の验り合いのみを考えればよい。各時間に扔い て節点での体積が一定であり、またループ圧力和の収支 が满足されていることが必要であることも非定常完全混 合の場合と同じである。完全混合の場合と異なる点は、 煙層の高さが時閒的に変化することおよび枝での流れの 処理が複䧴になり、Newton法を適用する場合の関係式が 複雑になることのみである。

前述の圧力仮定法による二首流非定常計算の場合々同 様に、ここでは空気層温度が一定かつ $d P / d t=0$ の場合を取 り扱うものとする。

流量仮定法の定式化のためには、ループ圧カに関する 関係式を用いる。(49)式の両辺に左からループ行列 $[L] を$ 乗 ヒ、、インシデンス行列とループ行列との関保 $[L]\left[I^{\prime}\right]=[0]$ を考慮すると、次のループ圧力に関する式を得る。

$$
\{0\}=[L]\left\{p+p_{\sigma}\right\}
$$

また、ループ行列が $[L]=\left[L_{t} \mid E\right]$ と表現できることを用い、 (47)式を変形して次式を得る。ただし、[E]は単位行列で ある。(Appendix(2)参照)

$$
C_{p}\{\overline{w T},\}=C_{p}\left[L_{t}^{\prime}\right]\{\overline{\tilde{w} T}\}+\left[I_{t}\right]^{-1}\left\{Q_{s}\right\}
$$

ただし、 $\overline{\tilde{w} T}$ はループに関する正味エネルギー流量であり、 添え字けはtreeの部分を取り出すことを意味する。この関倸 式は、ループの正味エネルギ流量と煙層での発熱量とが 与えられれば、木を構成する枝の正味エネルギ流量が計 算できることを示す。

(54)式を枝圧力差と枝流量との関係と組み合わせること により、枝の正味エネルギ流量が与えられた場合の枝圧 力差を求めることができる。その方法は非定常完全混合 の流量仮定法による計算の場合と基本的には同じである。 すなわち、枝圧力差 $p$ を仮定值として(23)式を満足する流 量wを逐次近似法によって求め、その值を用いて計算した 枝の正味エネルギ流量 $\overline{w T}$ と仮定した $\overline{w T}$ の值とが等しく なるように枝圧力差を補正しなおすという二重の逐次近 似を用いれば良い。なお、正味エネルギ流量誤差 $\Delta \overline{w T}$ と 仮定值の補正量 $\Delta p$ との関係は次式である。

$$
\{\Delta \overline{w T}\}=\left[\frac{\partial \overline{w T}}{\partial p}\right]\{\Delta p\}
$$

ただし $\left[\frac{\partial \overline{w T}}{\partial p}\right]$ は枝数 $\mathrm{x}$ 枝数の対角行列であり、次式で
与えられる対角要素を持つ。

$$
\frac{\partial \overline{w T}}{\partial p}=T_{s i} \frac{\partial w_{s}^{+}}{\partial p}-T_{s j} \frac{\partial w_{s}^{-}}{\partial p}+T_{a i} \frac{\partial w_{a}^{+}}{\partial p}-T_{a j} \frac{\partial w_{a}^{-}}{\partial p}
$$

ループの枝エネルギ流量が誤差 $\Delta \overline{\tilde{w} T}$ を持つと、(54)式 の関係からすべての枝流量が誤差を持ち、そのため(23)式 から決定される枝圧力差にも誤差を生じ、したがって(53) 式のループ圧力和の収支が満足されず誤差 $\Delta \tilde{p} を$ 生じる。 このときの誤差の関倸はNewton法を用いて整理すると次 のようになる。(Appendix(3)参照)

$$
\{\Delta \overline{\tilde{w} T}\}=\left([L]\left[\frac{1}{\frac{\partial \overline{\bar{T}}}{\partial p}}\right]\left[L^{\prime}\right]\right)^{-1}\{\Delta \tilde{p}\}
$$

この関係式は、ループ圧力和の収支の誤差からループ の正味エネルギ流量の仮定值の補正量を求めるのに用い

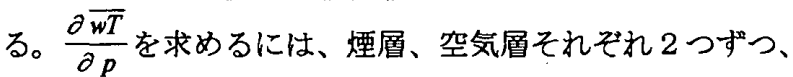
合計最大 4 個の和になるが、結果として一つにまとめる ことができるために、基本的には完全混合の場合と同様 に考えることができる。この関倸式の未知数は枝の正味 エネルギ流量であり、これは定常完全混合の場合の未知 数の数と同じであり、非定常二層流計算においてもグラ フの変更は必要としない。

非定常二層ゾーンモデルの場合の流量仮定法による計 算の流れを図-6に示す。

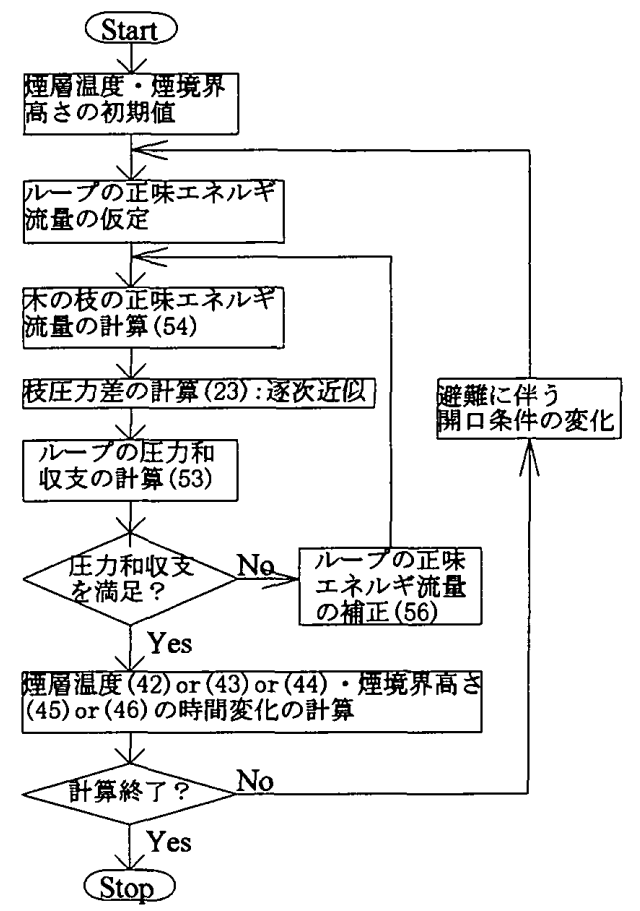

図-6 流量仮定法による非定常二層流煙流動計算の流れ

計算の各時間においては、煙温度と煙境界面高さが既 知として、(53)式で表されるループ圧力和が0になる関係 を満足する流れの場を求める。すなわち、ループの正味 エネルギ流量 $\overline{\tilde{w} T}$ を仮定し、(23)式の関係を満足する枝圧 
力差を逐次近似によって求め、それがループ圧力和の関 係(53)式を満たすまでループの正味エネルギ流量の補正を 繰り返す逐次近似計算法を用いる。

ループ圧力和の関係を满足する枝圧力差が求まってお り、この時間でのすべての枝の流量が同時に決定される ので、これらの值を用いることにより、次の時間ステッ プでの煙層温度および煙境界面高さが例えば(46)および (43)式から計算できる。

\section{7. 结論}

建物内の流れの回路いわゆる換気回路を表現するイン シデンス行列及びループ行列を用いた煙流動二層ソーン モデルの定式化を行った。空気層の温度を一定とし、 $d P / d t=0$ とする取り扱いにおいては、用いる基磪式の組み 合わせによっては得られる構成式に差を生じるが、この 差は $\left[T_{a}\right][I]\left\{w_{a}\right\} \approx[I]\left\{\bar{w}_{a}\right\}$ の近似が成立する場合には無視 しても良いことを示した。

インシデンス行列とループ行列を用いた二層ゾーンモ テルの圧力仮定法及び流量仮定法による計算法を示した。 二首ゾーンモデルの流量仮定法における赤知数は枝の正 味エネルギ流量であり、枝での煙流と空気流との和であ る正味流量を用いることにより完全混合の場合の圭知数 の数と同じになることを示した。非定常二層流計算にお いても完全混合の場合の計算からのグラフの変更は一切 必要とせず、完全混合の場合の考え方を単純に拡張でき、 計算が簡単になる。高層建築物などの建物内部全体での 煙流動の予測においては、流量仮定法の方が圧力仮定法 よりも解くべき連立方程式の元数が小さいことが多く、 計算時間が少なくてすむために、流量仮定法の利用が有 利となると考えられる。

\section{俢各立献}

1) 松下,寺井; 火烦時の開口部での湮と空気の流れ;日本建築学会計 画系論文集,No.481,1996.3(揭哉予定)

2) J.Prahl and H.W.Emmons; Fire Induced Flow through an Opening, Combustion and Flame, 25, 369-385, 1975

3) Tanaka; NBSIR 83-2718,1983

4) Matsushita, Fukai and Terai; Calculation of Smoke Movement in Building in case of Fire, Fire Safety Science - Proceedings of the First International Symposium, 1123-1132, 1985

5) 服部,小沢; グラフ理論解説,昭晃堂,1974

6) 前田,寺井,山口;日本建築学会大会学術譜演梗概集, 165-166,1968.10

7) Bird,et.al.;Transport Phenomena, p.323, Wiley Toppan, 1960

8) 日本建积センター; 喓流動及び避奞性状予測のための実用計算フ ロクラム解説宣, 1990

\section{記号}

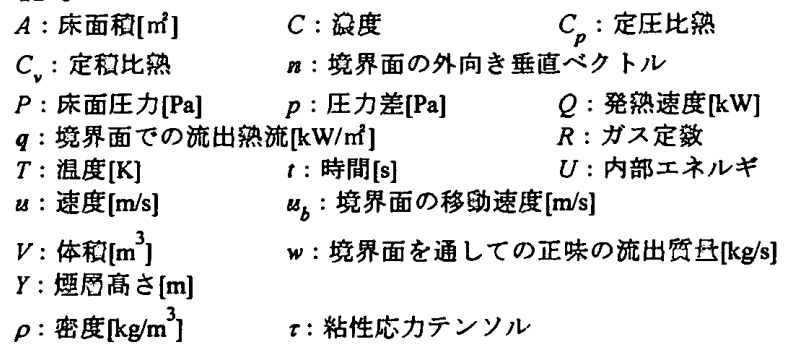

下付添元字

$a:$ 空気首

上付添え字

$s:$ 煙居

$+:$ 節点沫ら節点 $j$ の向き - : 節点から節点

Appendix

(1)圧力が誤差 $\triangle P$ を含むとき、開口での生力差にも誤差 $\Delta p を$ 生じる。 すなわち、

$$
\{p+\Delta p\}+\left\{p_{\sigma}\right\}=\left[I^{\prime}\right]\{P+\Delta P\}
$$

このときの虽差の関係式は、

$$
\{\Delta p\}=\left[I^{\prime}\right]\{\Delta P\}
$$

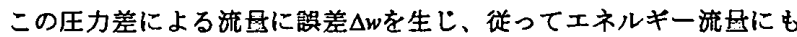
俱差 $\Delta \overline{w T}$ を生じる。

$$
\begin{gathered}
\quad\{\Delta \overline{w T}\}=\left[\frac{\partial \overline{w T}}{\partial p}\right]\{\Delta p\} \\
\text { ただし、 }\left[\frac{\partial \overline{w T}}{\partial p}\right] \text { は対角行列である。この開ロエネルキー流旦の誤 }
\end{gathered}
$$

差により、節点でのエネルギー収支に誤差 $\{\Delta Q\}$ が発生する。

$\{\Delta Q\}=[1]\{\Delta \overline{w T}\}$

以上の関係を、節点での流专収支誤差と飭点圧力偏差との関係とし てまとめると、次式となる。

$$
\left([I]\left[\frac{\partial \overline{w T}}{\partial p}\right]\left[I^{\prime}\right]\right)\{\Delta P\}=\{\Delta Q\}
$$

(2) $C_{p}[I]\left\{\frac{\bar{w} T}{w}\right\}=\left\{Q_{s}\right\}$ の变形を行う。ループを幥成する枝は一つの補 木とそれ以外の不を榭成する枝とで梅成される。ループのエネル ギー流区立T の向きと大きさを補不の向きと流量に等しくとること にする。ネを梅成する枝におけるエネルキー流量を店 $T$ とする。こ のとき、 $[I]=\left[I_{t} \mid \tilde{I}\right],\{\overline{w T}\}=\left\{\frac{\overline{w T}}{\overline{\bar{w} T}}\right\}$ と分解できることを利用すると、

$$
[I]\{\overline{w T}\}=\left[I_{t}\right]\left\{\overline{w T}_{t}\right\}+[\tilde{I}]\{\overline{\tilde{w} T}\}
$$

であるから、次式となる。

$$
C_{p}\left[I_{t}\right]\left\{\left[\overline{w T}_{t}\right\}+C_{p}[\tilde{I}]\{\overline{\tilde{w} T}\}=\left\{Q_{s}\right\}\right.
$$

ただし、 $\left[I_{t}\right]$ はインシテンス行列の木の枝に閣する部分行列、 $[\tilde{I}]$ は 補木の部分に閣する部分行列である。この式に、 $[L]=\left[L_{t} \mid E\right]$ と分解

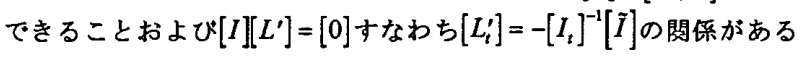
ことを適用すると、次のように变形できる。

$$
C_{p}\left\{\overline{w T}_{t}\right\}=C_{p}\left[L_{t}^{\prime}\right]\{\overline{\tilde{w} T}\}+\left[I_{t}\right]^{-1}\left\{Q_{s}\right\}
$$

(3)枝圧力差の誤差 $\Delta p$ とルーブ圧力の誤差 $\Delta \tilde{p}$ との間には次の閣保が ある。

$$
\{\Delta \tilde{\boldsymbol{p}}\}=[L]\{\Delta \boldsymbol{p}\}
$$

また、枝圧力差の誤差に伴う枝のエネルキー流量誤差 $\Delta \overline{w T}$ は次式で ある。

$$
\{\Delta \overline{w T}\}=\left[\frac{\partial \overline{w T}}{\partial p}\right]\{\Delta p\} \quad \therefore\{\Delta p\}=\left[\frac{\partial \overline{w T}}{\partial p}\right]^{-1}\{\Delta \overline{w T}\}
$$

(54)式を全ての枝について害き直し、その誤差の関係を求めると次 式となる。

$$
\begin{aligned}
& \{\Delta \overline{w T}\}=\left[\frac{L_{t}^{\prime}}{E}\right]\{\Delta \overline{\tilde{w} T}\}=\left[L^{\prime}\right]\{\Delta \overline{\tilde{w} T}\} \\
こ & \text { れらの関係式および }\left[\frac{\partial \overline{w T}}{\partial p}\right]^{-1}=\left[\frac{1}{\frac{\partial \overline{w T}}{\partial p}}\right] \text { を考嗤して、次式を得る。 } \\
& \left([L]\left[\frac{1}{\frac{\partial \overrightarrow{w T}}{\partial p}}\right]\left[L^{\prime}\right]\right)\{\Delta \overline{\tilde{w} T}\}=\{\Delta \tilde{p}\}
\end{aligned}
$$

（1995年 8 月 3 日原稿受理，1995年12月 5 日採用決定） 